Tsekhanovich V. B., Postgraduate Student

State Institution "Luhansk Taras Shevchenko National University" Luhansk, Ukraine

DOI: https://doi.org/10.30525/978-9934-26-068-1-23

\title{
FACTORS INFLUNCING THR DEVELOPMENT OF EUROREGIONAL COOPERATION IN THE INNOVATION SPHERE
}

Euroregional cooperation is an important tool for the development of the border territories of Ukraine with the EU, increasing their competitiveness, forming growth centers on them due to the advantages of territorial division and cooperation, as well as an important component of the European integration process. This is emphasized in the association agreement between Ukraine, on the one hand, and the European Union, the European Atomic Energy Community and their member states, on the other hand.

Today, in the context of modern geopolitical processes, the development of euroregional cooperation is extremely relevant. The process of Ukraine's entry into the European integration space and recognition by its European partners requires coordination of efforts to develop cooperation with EU member states and, first of all, Ukraine's neighbors.

Euroregional cooperation is characterized by the highest degree of institutionalization of cooperation structures and is a «catalyst» for European integration processes both at the regional and national levels of the state. The purpose of euroregional cooperation, as well as cross- 
border cooperation, is to level the functions of the state border and economic, social and cultural rapprochement of border regions on both sides by equalizing regional imbalances and increasing the level of socio-economic development of these territories.

Today, most regions of Ukraine have developed appropriate programs, concepts, and projects, the content of which is to approach the EU and activate cross-border cooperation. However, when trying to implement them, many unpredictable problems arise, and in some projects, the mechanisms for implementing them in practice are not always perfectly calculated. The legislative framework and licensing system, powers and responsibilities, lack of sufficient funding and use of funds from national investors are just a few constraints to achieving the goals declared by the regions.

Based on this, the key reasons for activating cross - border cooperation with the help of euroregions should be considered:

- a conscious desire of the heads of regional authorities and local self-government bodies under the border territories of Ukraine to institutionalize two-way cooperation with their partners from central and Eastern Europe for a more complete use of the potential advantages of spatial expansion of the relevant territories;

- the interest of representatives of public organizations, academia and other contact audiences in providing access to financial resources allocated under EU technical assistance programs for the implementation of infrastructure projects;

- attempts to transfer the main part of transcoder initiatives from the humanitarian plane that dominated the socialist period to the channel of economic relations related to the growth of exports and imports of goods and services, attracting foreign investments, developing transport infrastructure, and other areas of activation of cross-border business, which entails an increase in the economic potential of border territories and an increase in the volume of financial revenues to budgets of different levels;

- the desire of residents of border territories to get better and more complete access to the local markets of neighboring states, including through the development of infrastructure and other system- 
forming elements of cross-border markets, in order to solve their own social and economic problems through the intensification of border trade, strengthening labor-key motivations for activating cross-border cooperation with the help of euroregions should be considered;

- the conscious desire of the heads of regional authorities and local self-government bodies under the border territories of Ukraine to institutionalize two-way cooperation with their partners from central and Eastern Europe for a more complete use of the potential benefits of spatial expansion of the relevant territories.

These obstacles have the greatest impact on economic and environmental issues. They are largely based on excessive regulation (law, administration, political and economic interests, and competition), and to a lesser extent affect the social sphere, which is dominated by local activities such as «people for people». These most strongly hinder the implementation of strategic objectives include: differences in legal and administrative conditions (society, economy and environment); lack of public and private funds for the development of euroregions; lack of political commitment and different interests of regions and countries, as well as differences in environmental and environmental management conditions.

Euroregional cooperation helps attract financial resources from EU structural funds, which are mainly used for the implementation of joint projects of border adjacent regions, which is a common mechanism for solving problems and increasing regional competitiveness. However, such financing is targeted and involves attracting its own resources in the amount of 10-20\%. Therefore, financial support for euroregional cooperation should be considered as a mechanism that, when attracting a relatively small share of own funds, makes it possible to attract external financial resources and get a socio-economic effect in the border region. Thus, having more of your own financial resources allows you to implement more of your own and common goals, objectives, and projects.

In the innovation sphere of a territorial unit in euroregional cooperation and the level of its socio-economic development are interdependent concepts, since it is euroregional cooperation that is 
designed to help raise the socio-economic standards of the regions involved through the accumulation of efforts of the border territories of several countries to solve common pressing issues. Conversely, euroregional cooperation will be more effective in those regions where the base for innovation production has already been created, a large number of innovative-active enterprises are functioning, methods of production and implementation of innovations have been developed, as well as links between science, business and regional authorities have been established.

It should also be noted that the degree of state participation in the management of innovation processes in the region has a significant impact on the level of innovative development in the region. The main document defining the direction of state regulation is the law of Ukraine «on innovation activity», according to which state regulation of innovation activity is carried out by supporting priority areas of innovation activity at the regional level; formation and implementation of regional innovation programs; protection of the rights and interests of subjects of innovation activity; stimulation of credit and financial institutions that lend for the implementation of innovative projects; support for the functioning and development of modern innovation infrastructure, etc.

In addition, the degree of state influence is determined by the level of state funding for the innovation sector, which today is unsatisfactory in almost all regions of Ukraine. At the same time, the difference between state and own sources of financing for the regions is significant.

The development of euroregional cooperation in Ukraine is a driving force towards ensuring sustainable socio-economic growth of the regions. Cooperation within the regions creates prerequisites for the realization of human and scientific potential, the formation of export specialization of the regions, the development of international scientific and technical ties, and the deepening of cooperation with the EU as a whole. However, there are also a number of factors that hinder the expansion and deepening of cooperation in border areas, which is an incentive to find new forms of cooperation, such as 
attracting private capital to finance and implement innovative projects of euroregional cooperation, the development of innovative infrastructure, the implementation of innovative projects, and so on. 